\title{
DLL3 wt Allele
}

National Cancer Institute

\section{Source}

National Cancer Institute. DLL3 wt Allele. NCI Thesaurus. Code C104255.

Human DLL3 wild-type allele is located in the vicinity of $19 q 13$ and is approximately $10 \mathrm{~kb}$ in length. This allele, which encodes delta-like protein 3, plays a role in both neural cell differentiation and somitogenesis. Mutation of the gene is associated with spondylocostal dysostosis type 1 . 